\title{
Pengaruh Komposisi Pakan Buatan terhadap Perkembangbiakan Menochilus sexmaculatus Fabricius (Coleoptera: Coccinellidae)
}

\author{
Sudarjat ${ }^{1 *}$, Ani Rosmiyati ${ }^{2}$, Toto Sunarto ${ }^{1}$, dan Wawan Kurniawan ${ }^{1}$ \\ ${ }^{1}$ Departemen Hama dan Penyakit Tumbuhan, Fakultas Pertanian, Universitas Padjadjaran \\ ${ }^{2}$ Program Studi Agroteknologi, Fakultas Pertanian, Universitas Padjadjaran \\ Jalan Raya Bandung-Sumedang Km 21 \\ *Alamat korespondensi: sudarjat@unpad.ac.id
}

\begin{abstract}
Effect of Artificial Diet on the Development of Menochilus sexmaculatus Fabricius (Coleoptera: Coccinellidae)
\end{abstract}

Menochilus sexmaculatus is one of predators that preys on various kinds of insects including Aphididae, Coccidae, Diaspidae, and Aleyrodidae which attack ornamental plants, beans, corn, coffee, sugar cane, and tobacco. Artificial diet is needed in mass rearing of $M$. sexmaculatus. This research was objected to obtain the best composition of artificial diet for rearing $M$. sexmaculatus practically and efficiently. The experiment was arranged in the Randomized Block Design which consisted of 7 treatments of artificial diet and 1 treatment of natural diet, i.e. chicken liver flour, egg flour, soybean flour, chicken liver flour and egg flour (1:1), egg flour and soybean flour (1:1), soybean flour and chicken liver flour (1:1), chicken liver flour, egg flour and soybean flour (1:1:1), each of them were mixed with added materials of bread yeast, sugar, honey, vitamin $\mathrm{C}$, and vitamin E. Each treatment was repeated four times. The research results showed that $M$. sexmaculatus reared on artificial diet with the compositions of $30 \mathrm{~g}$ of egg flour $+20 \mathrm{~g}$ of added materials resulted in the best sum eggs number (157.25 eggs), percentage of hatching (92.54\%), number of larvae (145), number of adults (133) and percentage of adult emergence (91.67\%).

Keywords: Artificial diet, Life cycle, Menochilus sexmaculatus, Plant pest, Predator

\begin{abstract}
ABSTRAK
Menochilus sexmaculatus merupakan salah satu predator yang memangsa berbagai jenis serangga antara lain famili Aphididae, Coccidae, Diaspidae, dan Aleyrodidae yang menyerang tanaman hias, kacang-kacangan, jagung, kopi, tebu dan tembakau. Upaya perbanyakan serangga tersebut pada pakan alami seringkali menghadapi kendala. Penelitian ini bertujuan untuk mendapatkan komposisi pakan buatan yang paling baik untuk perkembangbiakan $M$. sexmaculatus sehingga dapat menunjang upaya pembiakkan massal yang lebih praktis dan efisien. Penelitian menggunakan metode percobaan dengan Rancangan Acak Kelompok (RAK) yang terdiri dari 8 perlakuan yaitu 7 perlakuan pakan buatan dan 1 perlakuan pakan alami. Komposisi utama pakan buatan yang diuji adalah tepung hati ayam, tepung telur, tepung kedelai, tepung hati ayam dan tepung telur (1:1), tepung telur dan tepung kedelai (1:1), tepung kedelai dan tepung hati ayam (1:1), tepung hati ayam, tepung telur dan tepung kedelai (1:1:1), yang masing-masing dicampur bahan tambahan berupa ragi roti, gula pasir, madu, vitamin $C$ dan vitamin E. Setiap perlakuan diulang empat kali. Hasil penelitian menunjukkan bahwa $M$. sexmaculatus yang diperbanyak pada pakan buatan dengan komposisi utama berupa $30 \mathrm{~g}$ tepung telur $+20 \mathrm{~g}$ bahan tambahan adalah komposisi pakan buatan yang paling baik dengan menghasilkan jumlah telur 157,25 butir, persentase penetasan telur 92,54\%, jumlah larva 145 ekor, jumlah imago 133 ekor dan persentase kemunculan imago $91,67 \%$.
\end{abstract}

Kata Kunci: Hama tanaman, Menochilus sexmaculatus, Pakan buatan, Predator, Siklus hidup 


\section{PENDAHULUAN}

Kumbang kubah Menochilus sexmaculatus Fabr. (Coleoptera ; Coccinellidae) merupakan salah satu predator yang memangsa berbagai jenis serangga antara lain famili Aphididae, Coccidae, Diaspidae dan Aleyrodidae yang dapat menyerang tanaman hias, kacang-kacangan, jagung, kopi, tebu dan tembakau (Omkar et al., 2006a). Umumnya kumbang ini banyak dijumpai pada berbagai tanaman di dataran rendah maupun dataran tinggi. M. sexmaculatus efektif mengendalikan kutu daun Aphis craccivora (Wagiman, 1997); (Omkar \& Bind, 2004), (Omkar et al., 2005), Aphis, Myzus, dan serangga dari golongan Aleyrodidae (Kalshoven, 1981). Di Indonesia penyebaran M. sexmaculatus ini sangat luas meliputi Jawa, Kalimantan, Sumatera, Sulawesi, Flores, Halmahera dan Papua (Setiawati, 2004).

Predator merupakan organisme yang hidup bebas dengan memakan, membunuh atau memangsa binatang lainnya (Untung, 2006). Serangga predator memiliki keunggulan, yaitu memiliki kemampuan memangsa dengan cepat, dapat membunuh berbagai stadium mangsa dan dapat mengonsumsi beberapa jenis mangsa (Erawati, 2005). Gerling et al., (2001) juga menyatakan bahwa ada beberapa spesies predator yang efektif memangsa Bemisia tabaci diantaranya adalah Coccinella transversalis dan $M$. sexmaculatus.

Selama ini, petani masih mengandalkan insektisida kimia sebagai salah satu usaha pengendalian. Penggunaan insektisida kimia selain berdampak positif, juga selalu diikuti oleh dampak negatif karena ada beberapa bahan aktif insektisida mempunyai spektrum daya bunuh yang luas dan akan mengakibatkan musnahnya musuh alami seperti parasitoid, predator, serangga berguna lainnya, dan serangga non target (Untung, 2006). Penggunaan pestisida kimia harus diminimalisasi dan salah satu alternatif pengendalian yang dapat dilakukan adalah pemanfaatan musuh alami seperti predator, parasitoid dan patogen (Irsan, 2003).

Teknik pengendalian hayati dengan menggunakan parasitoid dan predator dapat dikelompokkan dalam 3 kategori yaitu introduksi, augmentasi, dan konservasi. Augmentasi adalah usaha untuk mempertinggi daya guna musuh alami yang telah ada, misalnya dengan melakukan pembiakan secara massal dan menyebarkan kembali ke alam. Augmentasi dibagi menjadi dua yaitu inokulasi dan inundasi. Inokulasi adalah pelepasan musuh alami dalam jumlah terbatas yang bertujuan untuk meningkatkan populasi, sedangkan inundasi adalah pelepasan musuh alami dalam jumlah besar (Untung, 2006). Untuk menekan populasi kutu kebul B. tabaci di daerah endemik penyakit Gemini Virus, yaitu di Lampung dan Yogyakarta telah melepaskan predator $M$. sexmaculatus sebanyak 1 ekor/tanaman/bulan (Setiawati dkk., 2004). Oleh sebab itu, perlu dicari teknik pembiakan massal $M$. sexmaculatus.

Pembiakan massal serangga merupakan kegiatan pembiakan spesies serangga sesuai dengan jumlah yang diharapkan dengan teknik atau metode tertentu. Teknik pembiakan massal harus disesuaikan dengan pakan dan tempat atau lingkungan hidupnya di alam. Pakan buatan sudah berhasil digunakan untuk membiakan beberapa spesies predator (Matsuka et al., 1972 dalam Bain et al., 1984). Sebanyak 8 generasi spesies Coccinellidae berhasil dikembangbiakkan pada pakan yang terbuat dari kasein, sukrosa, gandum, kedelai hidrolisat, glikogen, lemak mentega, minyak jagung, hati, dekstrosa, ekstrak daun kapas (dengan karotenoid dan steroid), ragi bir, asam askorbat (Vitamin C), garam anorganik, vitamin dan agar.

Pakan buatan (artificial diet) telah umum digunakan untuk pembiakan massal banyak spesies serangga, baik untuk kepentingan penelitian maupun untuk dikomersialkan. Beberapa spesies serangga predator yang telah berhasil dibiakkan pada pakan buatan diantaranya Harmonia axyridis (Coleoptera ; Coccinellidae) (Matsuka et al., 1972; Okada et al., 1972), Hippodomia convergens (Coleoptera ; Coccinellidae) (Niijima et al., 1986). Perbanyakan serangga predator dari ordo Coccinellidae ini juga telah dilakukan di laboratorium.

Bahan baku utama pakan buatan yang sering digunakan yaitu wheat germ, torula yeast, kasein, dan tepung kedelai (Wheeler \& Zahniser, 2001; Avila et al., 2003; Cappellozza et al., 2005; Jacques et al., 2008). Beberapa pakan buatan yaitu sirup madu, sirup gula, dan air digunakan untuk perkembangbiakkan massal Coccinella septempunctata (Ashraf, 2010). Pakan buatan yang berasal dari hati unggas telah berhasil digunakan dalam pembiakan predator Coccinellidae (Bain et al., 1984). Penggunaan pakan buatan yang berasal dari hati mentah pertama kali dilakukan terhadap spesies dari Coccinellidae, Coleomegilla maculata (DeGeer) (Szumkowski, 1952 dalam Legner, 2000). Niijimi et al. (1986) kemudian membuat beberapa formulasi 
pakan buatan untuk pembiakan Harmonia axyridis. Larva berkembang dari instar 1-3 pada pakan yang mengandung 18 asam amino, sukrosa, kolesterol, 10 vitamin dan 6 mineral.

Pakan buatan dari hati ayam sangat baik digunakan untuk memperbanyak larva dan imago M. sexmaculatus (Hussein \& Haggen, 1990). Formulasi baru dari pakan yang terdiri dari bubuk hati ayam, sukrosa dan ragi bir berhasil diuji pada $M$. sexmaculatus sehingga lama hidup dan tingkat kesuburannya meningkat, jika dibandingkan dengan yang diberi kutu daun. Penambahan vitamin E dalam pakan buatan juga merangsang kesuburan dan perkawinan serangga dewasa. Tepung hati merupakan sumber protein yang relatif lebih mudah dicerna dan kandungan asam aminonya lebih lengkap, dan tepung hati adalah bahan baku pakan buatan untuk predator ini. Attallah \& Newsom (1966) telah berhasil memelihara 8 generasi spesies Coccinellidae pada pakan yang terbuat dari kasein, sukrosa, gandum, kedelai hidrolisat, glikogen, lemak mentega, minyak jagung, hati, dekstrosa, ekstrak daun kapas (dengan karotenoid dan steroid), ragi bir, asam askorbat (vitamin C), garam anorganik, vitamin dan agar.

Secara umum, nutrisi dalam makanan serangga dibagi ke dalam makronutrisi seperti protein, karbohidrat, lemak dan air, dan mikronutrisi seperti vitamin dan mineral (Barbehenn et al., 1999). Kualitas makanan bagi serangga secara signifikan memengaruhi kelangsungan hidup dan distribusi propagasi dari serangga (Barbehenn et al., 1999). Serangga predator lebih banyak membutuhkan asam amino yang didapatkan dari jaringan hewan dibandingkan karbohidrat (Chapman, 1998). Serangga fitofag umumnya memerlukan protein, asam amino dan karbohidrat hampir dalam jumlah yang sama seperti Orthoptera, Coleoptera, dan Lepidoptera (Chapman, 1998; Nation, 2001). Secara umum komponen utama pakan buatan terdiri atas hati ayam, sukrosa, ragi dan vitamin E (Thompson, 1999). Penelitian ini bertujuan untuk menguji beberapa komposisi pakan buatan dan pengaruhnya terhadap perkembangbiakan $M$. sexmaculatus.

\section{BAHAN DAN METODE}

Penelitian dilakukan dengan menggunakan metode eksperimen dengan Rancangan Acak Kelompok (RAK) yang terdiri atas 8 perlakuan dan 4 kali ulangan. Jumlah $M$. sexmaculatus untuk setiap perlakuan yaitu 2 ekor (1 pasang), satu ekor jantan dan satu ekor betina. Komposisi pakan buatan yang diuji masing-masing dibuat sebanyak $50 \mathrm{~g}$. Adapun komposisinya sebagai berikut:

Pakan alami (p0) : Kutu daun Rhopalosiphum maidis

Komposisi 1 (p1) : $30 \mathrm{~g}$ tepung hati ayam $+20 \mathrm{~g}$ bahan tambahan

Komposisi 2 (p2) : $30 \mathrm{~g}$ tepung telur $+20 \mathrm{~g}$ bahan tambahan

Komposisi 3 (p3) : $30 \mathrm{~g}$ tepung kedelai $+20 \mathrm{~g}$ bahan tambahan

Komposisi 4 (p4) : $15 \mathrm{~g}$ tepung hati ayam dan $15 \mathrm{~g}$ tepung telur $+20 \mathrm{~g}$ bahan tambahan

Komposisi 5 (p5) : $15 \mathrm{~g}$ tepung telur dan $15 \mathrm{~g}$ tepung kedelai $+20 \mathrm{~g}$ bahan tambahan

Komposisi 6 (p6) : $15 \mathrm{~g}$ tepung kedelai dan tepung hati ayam $+20 \mathrm{~g}$ bahan tambahan

Komposisi 7 (p7) : $10 \mathrm{~g}$ tepung hati ayam, $10 \mathrm{~g}$ tepung telur dan $10 \mathrm{~g}$ tepung kedelai $+20 \mathrm{~g}$ bahan tambahan

Keterangan: Bahan tambahan yang digunakan adalah ragi roti (10 g), gula pasir $(5 \mathrm{~g})$, madu (1 g), vitamin C (2 g) dan vitamin E (2 g).

\section{Penyediaan $M$. sexmaculatus}

Imago $M$. sexmaculatus yang digunakan dalam penelitian ini diperoleh dari pertanaman jagung di Arboretum, Universitas Padjadjaran dibawa ke laboratorium untuk dipelihara dan dibiakkan dalam kurungan kasa yang berukuran p: $60 \mathrm{~cm}, 1: 45 \mathrm{~cm}, \mathrm{t}: 45 \mathrm{~cm}$ di rumah kaca Jurusan Hama dan Penyakit Tumbuhan, Fakultas Pertanian Universitas Padjadjaran. M. sexmaculatus diberikan pakan berupa kutu daun $R$. maidis. Kelompok telur yang dihasilkan imago betina $M$. sexmaculatus diambil setiap hari, dan dipelihara secara terpisah dalam stoples. Setelah kelompok telur menetas maka larva dipindahkan ke stoples yang sudah disiapkan dan dipelihara sampai menjadi imago yang siap untuk diberi perlakuan.

\section{Penyediaan Pakan Alami dan Pakan Buatan}

Pakan alami $M$. sexmaculatus yang digunakan yaitu kutu daun $R$. maidis. Adapun pembuatan pakan buatan melalui beberapa tahap yaitu, pertama semua material yang diperlukan ditimbang sesuai dengan komposisi yang telah ditentukan, dihaluskan dengan menggunakan diblender selama 2 menit agar semua bahan tercampur. 
Proses pembuatan tepung hati ayam yaitu hati ayam direbus terlebih dahulu, dioven pada suhu $60^{\circ} \mathrm{C}$ selama 12 jam dan setelah kering diblender sehingga menjadi bentuk tepung, kemudian untuk membuat tepung telur yaitu telur dipecahkan dan diaduk hingga tercampur menjadi satu, cairan telur kemudian dituangkan ke dalam loyang yang sebelumnya telah diolesi minyak dan dioven pada suhu $45-50^{\circ} \mathrm{C}$ selama 6-16 jam, kemudian diblender menjadi bentuk tepung. Sedangkan untuk mendapatkan tepung kedelai yaitu dengan cara biji kedelai dimasukkan ke dalam blender hingga menjadi bentuk tepung.

\section{Uji Pakan Buatan}

Pakan buatan yang telah jadi, selanjutnya dimasukkan ke dalam stoples sesuai dengan jenis perlakuan. Setiap perlakuan dimasukkan satu pasang imago dan diberi pakan buatan sebanyak 0,5 g ke dalam stoples. Adapun perlakuan pembanding, imago $M$. sexmaculatus juga dipelihara dengan menggunakan pakan alaminya. Stoples dibersihkan dan diganti pakannya setiap 2 hari sekali. Stadia yang diamati yaitu stadia imago dengan maksud untuk melihat pengaruh pakan buatan terhadap lama hidup. Sedangkan jumlah telur diperoleh dengan menghitung telur yang dihasilkan.

\section{Analisis Data}

Data pengamatan terdiri dari data jumlah telur yang dihasilkan $M$. sexmaculatus, telur yang menetas, jumlah larva, dan jumlah imago keturunan pertama yang diperoleh dianalisis dengan uji ANOVA (Analysis of Variance). Adapun untuk mengetahui perbedaan antar perlakuan kemudian dilanjutkan dengan Uji Jarak Berganda Duncan pada taraf $5 \%$.

\section{HASIL DAN PEMBAHASAN}

\section{Pengaruh Pakan Buatan terhadap Jumlah $M$. sexmaculatus}

Berdasarkan hasil analisis, dapat diketahui bahwa perlakuan p0 (pakan alami) secara signifikan memberikan nilai rata-rata jumlah telur yang berbeda nyata bila dibandingkan dengan perlakuan pakan buatan p1 (30 g tepung hati ayam + $20 \mathrm{~g}$ bahan tambahan), p2 (30 g tepung telur $+20 \mathrm{~g}$ bahan tambahan), p3 (30 g tepung kedelai $+20 \mathrm{~g}$ bahan tambahan), p4 (15 g tepung hati ayam dan $15 \mathrm{~g}$ tepung telur + $20 \mathrm{~g}$ bahan tambahan), p5 (15 tepung telur dan $15 \mathrm{~g}$ tepung kedelai $+20 \mathrm{~g}$ bahan tambahan), p6 (15 g tepung kedelai dan $15 \mathrm{~g}$ tepung hati ayam + $20 \mathrm{~g}$ bahan tambahan), dan p7 (10 g tepung hati ayam, $10 \mathrm{~g}$ tepung telur dan $10 \mathrm{~g}$ tepung kedelai $+20 \mathrm{~g}$ bahan tambahan) (tabel 1). Jumlah telur yang dihasilkan pada perlakuan pakan alami adalah 221,75 butir (Tabel 1). Di antara perlakuan pakan buatan, perlakuan p2 (30 g tepung telur $+20 \mathrm{~g}$ bahan tambahan) merupakan pakan buatan terbaik yang mampu menghasilkan telur sebanyak 157,25 butir dan berbeda nyata dengan perlakuan pakan buatan lainnya.

Tabel 1. Rata-rata jumlah telur M. sexmaculatus pada pemberian pakan buatan

\begin{tabular}{|c|c|c|c|}
\hline & & Perlakuan & $\begin{array}{l}\text { Rata-rata jumlah telur } \\
\text { (butir/ekor) }\end{array}$ \\
\hline p0 & : & Pakan alami (Rhopalosiphum maidis) & $221,75 \pm 12,83 \mathrm{a}$ \\
\hline p1 & : & $30 \mathrm{~g}$ tepung hati ayam $+20 \mathrm{~g}$ bahan tambahan & $34,00 \pm 7,32 \mathrm{~d}$ \\
\hline p2 & : & $30 \mathrm{~g}$ tepung telur $+20 \mathrm{~g}$ bahan tambahan & $157,25 \pm 15,33 b$ \\
\hline p3 & : & $30 \mathrm{~g}$ tepung kedelai $+20 \mathrm{~g}$ bahan tambahan & $8,00 \pm 12,32 \mathrm{e}$ \\
\hline p4 & : & $15 \mathrm{~g}$ tepung hati ayam $+15 \mathrm{~g}$ tepung telur $+20 \mathrm{~g}$ bahan tambahan & $44,00 \pm 11,12 \mathrm{~cd}$ \\
\hline p5 & : & $15 \mathrm{~g}$ tepung telur $+15 \mathrm{~g}$ tepung kedelai $+20 \mathrm{~g}$ bahan tambahan & $35,50 \pm 21,66 \mathrm{~d}$ \\
\hline p6 & : & $15 \mathrm{~g}$ tepung kedelai $+15 \mathrm{~g}$ tepung hati ayam $+20 \mathrm{~g}$ bahan tambahan & $32,75 \pm 34,22 \mathrm{~d}$ \\
\hline p7 & : & $\begin{array}{l}10 \mathrm{~g} \text { tepung hati ayam }+10 \mathrm{~g} \text { tepung telur }+10 \mathrm{~g} \text { tepung kedelai }+20 \\
\mathrm{~g} \text { bahan tambahan }\end{array}$ & $71,00 \pm 15,62 \mathrm{c}$ \\
\hline
\end{tabular}

Keterangan: Nilai rata-rata yang diikuti huruf yang sama pada kolom yang sama menunjukkan tidak berbeda nyata menurut Uji Jarak Berganda Duncan pada taraf nyata 5\%.

Jumlah telur yang dihasilkan oleh perlakuan p2 (30 g tepung telur $+20 \mathrm{~g}$ bahan tambahan sebanyak 157,25 butir) tidak jauh berbeda dengan hasil penelitian yang dilakukan oleh Omkar et al. (2006a) yakni 132-161 butir. Hal ini disebabkan tepung telur mempunyai kandungan protein yang lebih tinggi jika dibandingkan dengan tepung hati ayam dan kedelai. Protein merupakan 
komponen penting untuk mengeluarkan juvenil hormon (JH) yang diperlukan untuk ovarium dan perkembangan telur (Nation, 2001). Nutrisi yang berupa protein dibutuhkan oleh serangga betina untuk proses pematangan telur yang akan diletakkan (De Bach (1973). Chapman (1998) menyatakan bahwa pakan yang dikonsumsi oleh imago betina dan jantan akan berdampak langsung terhadap reproduksi serangga tersebut. Selain protein, nutrisi lain pada pakan yang diperlukan oleh serangga diantaranya adalah lemak. Salah satu fungsi lemak yaitu untuk mensintesis hormon ekdison yang dapat memengaruhi perkembangan serangga (Chapman, 1998). Berdasarkan semua perlakuan yang diuji pada penelitian ini, kandungan lemak yang paling rendah terdapat pada perlakuan p3 (tepung kedelai $+20 \mathrm{~g}$ bahan tambahan) ddengan rata-rata jumlah telur sebanyak 8,00 butir.

\section{Persentase Penetasan Telur $M$. sexmaculatus}

Berdasarkan jumlah telur yang dihasilkan, persentase penetasan telur yang paling tinggi dihasilkan oleh perlakuan p7 (10 g tepung hati ayam, $10 \mathrm{~g}$ tepung telur dan $10 \mathrm{~g}$ tepung kedelai +20 bahan tambahan), yaitu 97,42\%. Sedangkan yang terendah dihasilkan oleh perlakuan p3 (30 g tepung kedelai + bahan tambahan), yaitu 65,62\%. Telur $M$. sexmaculatus yang tidak menetas, diduga karena kegagalan sperma membuahi telur walaupun sebelumnya serangga berkopulasi. Hasil penelitian Omkar et al. (2006a) menyatakan bahwa meskipun M. sexmaculatus berkopulasi, tetapi dapat terjadi jumlah sperma sangat sedikit untuk membuahi sel telur (Tabel 2).

Tabel 2. Pengaruh pemberian pakan buatan terhadap persentase penetasan telur $M$. sexmaculatus

\begin{tabular}{|c|c|c|c|}
\hline & & Perlakuan & $\begin{array}{l}\text { Penetasan telur } \\
(\%)\end{array}$ \\
\hline p0 & : & Pakan alami (Rhopalosiphum maidis) & $87,68 \pm 5,75 b$ \\
\hline p1 & : & $30 \mathrm{~g}$ tepung hati ayam $+20 \mathrm{~g}$ bahan tambahan & $92,63 \pm 7,21 \mathrm{ab}$ \\
\hline p2 & : & $30 \mathrm{~g}$ tepung telur $+20 \mathrm{~g}$ bahan tambahan & $92,54 \pm 3,33 \mathrm{ab}$ \\
\hline p3 & : & $30 \mathrm{~g}$ tepung kedelai $+20 \mathrm{~g}$ bahan tambahan & $65,62 \pm 12,64 c$ \\
\hline $\mathrm{p} 4$ & : & $15 \mathrm{~g}$ tepung hati ayam $+15 \mathrm{~g}$ tepung telur $+20 \mathrm{~g}$ bahan tambahan & $96,03 \pm 3,27$ a \\
\hline p5 & : & $15 \mathrm{~g}$ tepung telur $+15 \mathrm{~g}$ tepung kedelai $+20 \mathrm{~g}$ bahan tambahan & $96,96 \pm 6,07 \mathrm{a}$ \\
\hline p6 & : & $\begin{array}{l}15 \mathrm{~g} \text { tepung kedelai }+15 \mathrm{~g} \text { tepung hati ayam }+20 \mathrm{~g} \text { bahan } \\
\text { tambahan }\end{array}$ & $89,02 \pm 12,29 \mathrm{ab}$ \\
\hline p7 & : & $\begin{array}{l}10 \mathrm{~g} \text { tepung hati ayam }+10 \mathrm{~g} \text { tepung telur }+10 \mathrm{~g} \text { tepung kedelai }+ \\
20 \mathrm{~g} \text { bahan tambahan }\end{array}$ & $97,42 \pm 1,78 \mathrm{a}$ \\
\hline
\end{tabular}

Keterangan: Nilai rata-rata yang diikuti huruf yang sama pada kolom yang sama menunjukkan tidak berbeda nyata menurut Uji Jarak Berganda Duncan pada taraf nyata 5\%.

Pemberian pakan buatan untuk $M$. sexmaculatus ternyata tidak memengaruhi fertilitas telur, kecuali pakan buatan yang terbuat dari tepung kedelai (perlakuan p3). Pemberian pakan yang terbuat dari tepung kedelai, selain menurunkan fekunditas juga menurunkan fertilitasnya sampai $65,62 \%$, sedangkan dengan pemberian pakan buatan yang terbuat dari hati ayam dan tepung telur fekunditasnya masih tetap tinggi, berkisar 89,0296,96\%. Hal ini diduga karena kandungan protein yang berbeda pada perlakuan p3 (kandungan asam amino lebih rendah).

Pengaruh Pakan Buatan terhadap Jumlah Larva $M$. sexmaculatus

Berdasarkan hasil analisis, dapat diketahui bahwa perlakuan pakan alami ( $R$. maidis) secara signifikan memberikan nilai rata-rata jumlah larva yang dihasilkan berbeda nyata bila dibandingkan dengan seluruh perlakuan pakan buatan. Jumlah larva yang dihasilkan oleh perlakuan pakan alami ( $R$. maidis) sebanyak 193 ekor. Di antara perlakuan pakan buatan, perlakuan p2 (30 g tepung telur $+20 \mathrm{~g}$ bahan tambahan) merupakan perlakuan dengan jumah larva yang paling tinggi dan berbeda nyata bila dibandingkan dengan perlakuan pakan buatan lainnya. Jumlah larva yang dihasilkan pada perlakuan p2 (30 g tepung telur $+20 \mathrm{~g}$ bahan tambahan) ini adalah sebanyak 145 ekor (Tabel 3).

Perlakuan p2 (30 g tepung telur $+20 \mathrm{~g}$ bahan tambahan) merupakan perlakuan yang paling baik di antara pemberian pakan buatan lainnya. Jumlah larva yang dihasilkan pada perlakuan p2 (30 $\mathrm{g}$ tepung telur $+20 \mathrm{~g}$ bahan tambahan) tersebut 
sebesar 145 ekor. Kebutuhan nutrisi bagi serangga ditentukan berdasarkan kualitas dan kuantitas makanan yang diberikan sehingga sangat berpengaruh terhadap perkembangan dan pertumbuhan pada berbagai stadia serangga termasuk stadia larva yang dihasilkan (Ross et al., 1982; Okada \& Maehava, 1972; Omkar \& Pervez, 2006a; Omkar et al., 2005). Hal tersebut dapat dibuktikan pada $M$. sexmaculatus yang diberi pakan tepung kedelai menghasikan larva 5,50 ekor. Pada pakan yang tebuat dari tepung kedelai, walaupun kandungan proteinnya cukup tinggi tetapi karena kemungkinan besar kandungan asam amino yang dibutuhkan oleh predator $M$. sexmaculatus kurang terpenuhi maka jumlah larva yang dihasilkan juga sangat rendah. Rendahnya nutrisi pakan dapat menyebabkan rendahnya reproduksi, pertumbuhan dan perkembangan seluruh stadia serangga. Serangga umumnya memilih pakan yang memiliki kombinasi nutrisi seimbang (Avila et al., 2003).

Tabel 3. Rata-rata jumlah larva $M$. sexmaculatus pada berbagai pemberian pakan buatan

\begin{tabular}{|c|c|c|c|}
\hline & & Perlakuan & $\begin{array}{l}\text { Rata-rata jumlah larva } \\
\text { (ekor) }\end{array}$ \\
\hline p0 & : & Pakan alami (Rhopalosiphum maidis) & $193,00 \pm 22,10 \mathrm{a}$ \\
\hline p1 & : & $30 \mathrm{~g}$ tepung hati ayam $+20 \mathrm{~g}$ bahan tambahan & $31,80 \pm 17,22 \mathrm{c}$ \\
\hline p2 & : & $30 \mathrm{~g}$ tepung telur $+20 \mathrm{~g}$ bahan tambahan & $145,00 \pm 21,63 b$ \\
\hline p3 & : & $30 \mathrm{~g}$ tepung kedelai $+20 \mathrm{~g}$ bahan tambahan & $5,50 \pm 16,20 \mathrm{~d}$ \\
\hline $\mathrm{p} 4$ & : & $15 \mathrm{~g}$ tepung hati ayam $+15 \mathrm{~g}$ tepung telur $+20 \mathrm{~g}$ bahan tambahan & $41,50 \pm 12,49 \mathrm{bc}$ \\
\hline p5 & : & $15 \mathrm{~g}$ tepung telur $+15 \mathrm{~g}$ tepung kedelai $+20 \mathrm{~g}$ bahan tambahan & $33,50 \pm 16,83 c$ \\
\hline p6 & : & $15 \mathrm{~g}$ tepung kedelai $+15 \mathrm{~g}$ tepung hati ayam $+20 \mathrm{~g}$ bahan tambahan & $29,75 \pm 14,22 \mathrm{c}$ \\
\hline p7 & : & $\begin{array}{l}10 \mathrm{~g} \text { tepung hati ayam }+10 \mathrm{~g} \text { tepung telur }+10 \mathrm{~g} \text { tepung kedelai }+20 \mathrm{~g} \\
\text { bahan tambahan }\end{array}$ & $68,75 \pm 9,23 \mathrm{c}$ \\
\hline
\end{tabular}

Keterangan: Nilai rata-rata yang diikuti huruf yang sama pada kolom yang sama menunjukkan tidak berbeda nyata menurut Uji Jarak Berganda Duncan pada taraf nyata 5\%.

Pengaruh Pakan Buatan terhadap Jumlah dan Persentase Kemunculan Imago M. Sexmaculatus.

Berdasarkan hasil analisis, dapat diketahui bahwa perlakuan p0 (pakan alami) secara signifikan memberikan nilai rata-rata jumlah imago yang paling tinggi dan berbeda nyata bila dibandingkan dengan seluruh perlakuan pakan buatan dengan jumlah imago sebesar 180,75 ekor. Di antara perlakuan pakan buatan yang diuji, p2 (30 g tepung telur $+20 \mathrm{~g}$ bahan tambahan) merupakan perlakuan terbaik dengan jumlah imago yang dihasilkan sebesar 133 ekor, jumlah yang paling tinggi dan berbeda nyata bila dibandingkan dengan perlakuan pakan buatan lainnya (Tabel 4). Hal ini menunjukkan bahwa kemunculan imago dipengaruhi oleh kualitas maupun kuantitas pakan buatan yang diberikan, pakan dengan kualitas kandungan nutrisi yang cukup dan seimbang akan memberikan perkembangan dan pertumbuhan setiap stadia serangga dengan baik termasuk larva yang dapat lolos hidup menjadi pupa dan pupa yang dapat lolos hidup menjadi imago. Ros et al., (1982) menyatakan bahwa perkembangan populasi serangga pada pertanaman akan sangat terpengaruh oleh keberadaan pakan yang tersedia. Jika jumlah pakan yang tersedia kurang maka perkembangan dan jumlah populasi dari serangga tersebut akan terhambat. Miller dan Miller (1986) menambahkan bahwa serangga akan lebih menyukai pakan atau tanaman inang yang banyak mengandung senyawasenyawa karbohidrat (glukosa, fruktosa, sukrosa dan rafinosa), protein, lemak dan kadar air yang tinggi.

Jika dilihat dari persentase kemunculan imago $M$. sexmaculatus, pakan alami dan pakan buatan p2 (30 g tepung telur + $20 \mathrm{~g}$ bahan tambahan) menghasilkan persentase kemunculan imago yang paling tinggi dibandingkan perlakuan pakan buatan lainnya yakni masing-masing sebesar $94.15 \%$ dan $91.67 \%$ (Gambar 2). Tingginya persentase kemunculan imago kemungkinan besar disebabkan oleh cukupnya kandungan nutrisi yang dibutuhkan untuk penetasan pupa menjadi imago yang memerlukan energy besar saat berlangsungnya penetasan. Kurangnya nutrisi yang diberikan saat stadia larva, akan mengakibatkan berkurangnya larva yang berhasil membentuk pupa dan berkurangnya pupa yang berhasil menjadi imago (Chapman, 1998: Niijima \&d Okada, 1986). Keseimbangan nutrisi pakan yang diberikan sangat penting dalam perkembangan dan pertumbuhan serangga, salah satunya adalah kandungan lemak. Salah satu fungsi lemak yaitu untuk mensintesis 
hormon ekdison yang dapat memengaruhi perkembangan serangga. Proses ganti kulit larva instar II menjadi instar III dan seterusnya atau akan berubah menjadi pupa dan imago, sangat ditentukan oleh peranan hormon yang terdapat pada serangga.
Salah satu hormon yang berperan dalam proses pertumbuhan dan perkembanan serangga yaitu juvenile hormon (JH) (Chapman, 1998; Thompson, 1999; Omkar \& Singh, 2006b).

Tabel 4. Rata-rata jumlah imago $M$. sexmaculatus dan persentase kemunculan imago pada pemberian pakan buatan

\begin{tabular}{|c|c|c|}
\hline & Perlakuan & $\begin{array}{l}\text { Rata-rata jumlah imago } \\
\text { (ekor) }\end{array}$ \\
\hline p0 & Pakan alami (Rhopalosiphum maidis) & $180,75 \pm 23,32 \mathrm{a}$ \\
\hline p1 & : $30 \mathrm{~g}$ tepung hati ayam $+20 \mathrm{~g}$ bahan tambahan & $20,25 \pm 12,33 \mathrm{~cd}$ \\
\hline p2 & $30 \mathrm{~g}$ tepung telur $+20 \mathrm{~g}$ bahan tambahan & $133,00 \pm 33,21 b$ \\
\hline p3 & $30 \mathrm{~g}$ tepung kedelai $+20 \mathrm{~g}$ bahan tambahan & $4,25 \pm 11,39 \mathrm{e}$ \\
\hline $\mathrm{p} 4$ & $\begin{array}{l}15 \mathrm{~g} \text { tepung hati ayam }+15 \mathrm{~g} \text { tepung telur }+20 \mathrm{~g} \text { bahan } \\
\text { tambahan }\end{array}$ & $29,50 \pm 19,36 \mathrm{~cd}$ \\
\hline p5 & $\begin{array}{l}15 \mathrm{~g} \text { tepung telur }+15 \mathrm{~g} \text { tepung kedelai }+20 \mathrm{~g} \text { bahan } \\
\text { tambahan }\end{array}$ & $22,25 \pm 15,83 \mathrm{~cd}$ \\
\hline p6 & $\begin{array}{l}15 \mathrm{~g} \text { tepung kedelai }+15 \mathrm{~g} \text { tepung hati ayam }+20 \mathrm{~g} \text { bahan } \\
\text { tambahan }\end{array}$ & $12,75 \pm 13,47 \mathrm{de}$ \\
\hline p7 & $\begin{array}{l}10 \mathrm{~g} \text { tepung hati ayam }+10 \mathrm{~g} \text { tepung telur }+10 \mathrm{~g} \text { tepung } \\
\text { kedelai }+20 \mathrm{~g} \text { bahan tambahan }\end{array}$ & $42,75 \pm 17,88 \mathrm{c}$ \\
\hline
\end{tabular}

Keterangan: Nilai rata-rata yang diikuti huruf yang sama pada kolom yang sama menunjukkan tidak berbeda nyata menurut Uji Jarak Berganda Duncan pada taraf nyata 5\%.

Tabel 5. Pengaruh pemberian pakan buatan terhadap persentase kemunculan imago M. sexmaculatus

\begin{tabular}{|c|c|c|c|}
\hline & & Perlakuan & $\begin{array}{l}\text { Kemunculan Imago } \\
(\%)\end{array}$ \\
\hline p0 & : & Pakan alami (Rhopalosiphum maidis) & $94,15 \pm 4,55$ \\
\hline $\mathrm{p} 1$ & : & $30 \mathrm{~g}$ tepung hati ayam $+20 \mathrm{~g}$ bahan tambahan & $72,62 \pm 18,47$ \\
\hline p2 & : & $30 \mathrm{~g}$ tepung telur $+20 \mathrm{~g}$ bahan tambahan & $91,67 \pm 1,69$ \\
\hline p3 & : & $30 \mathrm{~g}$ tepung kedelai $+20 \mathrm{~g}$ bahan tambahan & $68,92 \pm 28,53$ \\
\hline $\mathrm{p} 4$ & : & $\begin{array}{l}15 \mathrm{~g} \text { tepung hati ayam }+15 \mathrm{~g} \text { tepung telur }+20 \mathrm{~g} \text { bahan } \\
\text { tambahan }\end{array}$ & $79,18 \pm 20,41$ \\
\hline p5 & : & $\begin{array}{l}15 \mathrm{~g} \text { tepung telur }+15 \mathrm{~g} \text { tepung kedelai }+20 \mathrm{~g} \text { bahan } \\
\text { tambahan }\end{array}$ & $68,80 \pm 21,02$ \\
\hline p6 & : & $\begin{array}{l}15 \mathrm{~g} \text { tepung kedelai }+15 \mathrm{~g} \text { tepung hati ayam }+20 \mathrm{~g} \text { bahan } \\
\text { tambahan }\end{array}$ & $51,85 \pm 32,59$ \\
\hline p7 & : & $\begin{array}{l}10 \mathrm{~g} \text { tepung hati ayam }+10 \mathrm{~g} \text { tepung telur }+10 \mathrm{~g} \text { tepung } \\
\text { kedelai }+20 \mathrm{~g} \text { bahan tambahan }\end{array}$ & $59,85 \pm 10,40$ \\
\hline
\end{tabular}

Keterangan: Nilai rata-rata yang diikuti huruf yang sama pada kolom yang sama menunjukkan tidak berbeda nyata menurut Uji Jarak Berganda Duncan pada taraf nyata 5\%.

\section{Pengaruh Pakan Buatan Terhadap Lama Hidup Imago $M$. sexmaculatus}

Hasil pengamatan rata-rata lama hidup $M$. sexmaculatus pada pemberian pakan buatan menunjukan bahwa pakan buatan memberikan pengaruh terhadap lama hidup $M$. sexmaculatus (Tabel 6). Rata-rata lama hidup imago betina paling lama dihasilkan pada perlakuan p2 (30 g tepung telur + 20 bahan tambahan) selama 31,75 hari dan lama hidup paling pendek dihasilkan pada perlakuan p5 (15 g tepung telur $+15 \mathrm{~g}$ tepung kedelai $+20 \mathrm{~g}$ bahan tambahan tambahan) selama 19,75 hari. Sedangkan rata-rata lama hidup imago jantan paling lama dihasilkan pada perlakuan p0 (pakan alami) selama 34 hari dan lama hidup paling pendek dihasilkan pada perlakuan p6 (15 g tepung kedelai + $15 \mathrm{~g}$ tepung hati ayam $+20 \mathrm{~g}$ bahan tambahan 
tambahan) selama 20,75 hari. Bateman (1972), mengandung asam amino, vitamin, air dan menyatakan bahwa kualitas dan kuantitas pakan karbohidrat dapat memperpanjang umur serta akan berpengaruh terhadap perkembangan populasi meningkatkan keperidian serangga.

larva, pupa dan imago. Jenis pakan yang banyak

Tabel 6. Rata-rata lama hidup imago M. sexmaculatus pada pemberian pakan buatan

\begin{tabular}{|c|c|c|c|c|}
\hline \multirow{2}{*}{\multicolumn{3}{|c|}{ Perlakuan }} & \multicolumn{2}{|c|}{ Rata-rata lama hidup imago } \\
\hline & & & $\begin{array}{l}\text { Betina } \pm \text { SD } \\
\quad \text { (hari) }\end{array}$ & $\begin{array}{l}\text { Jantan } \pm \text { SD } \\
\text { (hari) }\end{array}$ \\
\hline p0 & : & Pakan alami (Rhopalosiphum maidis) & $31,25 \pm 0,96$ & $34,00 \pm 4,08$ \\
\hline p1 & : & $30 \mathrm{~g}$ tepung hati ayam $+20 \mathrm{~g}$ bahan tambahan & $27,00 \pm 4,83$ & $29,25 \pm 2,87$ \\
\hline p2 & : & $30 \mathrm{~g}$ tepung telur $+20 \mathrm{~g}$ bahan tambahan & $31,75 \pm 1,71$ & $33,25 \pm 2,22$ \\
\hline p3 & : & $30 \mathrm{~g}$ tepung kedelai $+20 \mathrm{~g}$ bahan tambahan & $20,25 \pm 4,03$ & $23,50 \pm 2,65$ \\
\hline $\mathrm{p} 4$ & : & $\begin{array}{l}15 \mathrm{~g} \text { tepung hati ayam }+15 \mathrm{~g} \text { tepung telur }+20 \mathrm{~g} \text { bahan } \\
\text { tambahan }\end{array}$ & $27,50 \pm 6,14$ & $30,50 \pm 3,51$ \\
\hline p5 & : & $\begin{array}{l}15 \mathrm{~g} \text { tepung telur }+15 \mathrm{~g} \text { tepung kedelai }+20 \mathrm{~g} \text { bahan } \\
\text { tambahan tambahan }\end{array}$ & $19,75 \pm 1,71$ & $21,75 \pm 2,50$ \\
\hline p6 & : & $\begin{array}{l}15 \mathrm{~g} \text { tepung kedelai }+15 \mathrm{~g} \text { tepung hati ayam }+20 \mathrm{~g} \\
\text { bahan tambahan tambahan }\end{array}$ & $21,25 \pm 5,56$ & $20,75 \pm 3,59$ \\
\hline p7 & : & $\begin{array}{l}10 \mathrm{~g} \text { tepung hati ayam }+10 \mathrm{~g} \text { tepung telur }+10 \mathrm{~g} \text { tepung } \\
\text { kedelai }+20 \mathrm{~g} \text { bahan tambahan }\end{array}$ & $27,50 \pm 1,73$ & $28,50 \pm 2,08$ \\
\hline
\end{tabular}

Keterangan: SD = Standar Deviasi

\section{SIMPULAN}

Pakan buatan dengan komposisi utama berupa $30 \mathrm{~g}$ tepung telur $+20 \mathrm{~g}$ bahan tambahan (ragi roti, gula pasir, madu, vitamin $\mathrm{C}$ dan vitamin $\mathrm{E}$ ) merupakan komposisi bakan buatan yang mampu memberikan hasil lebih baik terhadap jumlah telur $(157,25$ butir/ekor betina), persentase penetasan telur (92,54\%), jumlah larva (145 ekor), jumlah imago (133 ekor), persentase kemunculan imago $(91,67 \%)$ serta kelangsungan hidup imago betina (31,75 hari).

\section{DAFTAR PUSTAKA}

Ashraf, M. 2010. A study on laboratory rearing of lady bird beetle (Coccinella septempunctata) to observe its fecundity and longevity on natural and artificial diets. International Journal of Biology. 2(1): 165173.

Attallah, YH, and LD Newsom. 1966. Ecological and nutritional studies on Coleomegilla maculata DeGeer (Coleoptera: Coccinellidae). I. The development of an artificial diet and a laboratory rearing technique. J. Econ. Ent. 59: 1173-79.
Avila, TO, HA Woods, and RA Raguso. 2003. Effect of dietary variation on growth, composition, and maturation of Manduca sexta (Lepidoptera; Sphingidae). Journal of Insect Physiology. 49: 293-306.

Bain, J, S Pritam, MD Ashby, and RJ Van Boven. 1984. Laboratory rearing of the predatory Coccinellid Cleobora mellyi (Coleoptera; Coccinellidae) for biological control of Paropsis charybdis (Coleoptera; Chrysomelidae) in New Zealand. Entomophaga (2): 237-244.

Barbehenn, RV, JC Reese, and KS Hagen. 1999. In Pp. 83-121. Ecological Entomology (CB Huffaker, AP Gutierrez, Eds.). John Wiley \& Sons, Inc. New York.

Bateman, MA. 1972. The ecology of fruit flies. Ann. Rev. Entomology. 17: 496-514.

Cappelozza, L, S Cappelozza, A Saviane, and G Sbrenna. 2005. Artificial diet rearing system for the Bombyx mori (Lepidoptera; Bombycidae) effect of vitamin $C$ deprivation on larval growth and cocoon production. Applied Entomology and Zoology. 40 (3): 69-74.

Chapman, RF. 1998. The Insects: Structure and Function. Cambridge University Press. UK. 770p. 
De Bach, P. 1973. Biological Control of Insect, Pest and Weeds. Chap and Hall. New York.

Erawati, W. 2005. Perilaku dan Siklus Hidup Sycanus annulicornis Dohrn. Asal Tanaman Kedelai pada Mangsa Larva Spodoptera litura (F.) [Skripsi]. Institut Pertanian Bogor. Bogor.

Gerling, D., O Alomar and J Arno. 2001. Biological Control of Bemisia tabaci Using Predators and Parasitoids. Crop Protection. 20(9): 779799.

Hussein, MY, and KS Haggen. 1990. Rearing of Hippodomia convergens on artificial diet of chicken liver, yeast and sucrose. Entomol.exp. appl. 59: 197-199.

Irsan, C. 2003. Predator, parasitoid, dan hiperparasitoid yang berasosiasi dengan kutu daun (Homoptera: Aphididae). Hayati. 10: 81-84.

Jacques, MM, E Despland, and JC Bede. 2008. Nutrient utilizatian by caterpillars of the generalist beet armyworm, Spodoptera exigua. Physiologycal Entomology. 33: 5156.

Kalshoven, LGE. 1981. The Pest of Crops in Indonesia. PT Ichtiar Baru van Hoeve. Jakarta.

Legner, EF. 2000. Nutrition of Arthropod Natural Enemies. Available online at http://www.faculty.ucr.edu/ legneref/biotac t/bc-57.htm. Diakses 1 Juli 2020.

Matsuka, M, D Shimotori, T Senzaki, and I Okada. 1972. Rearing some Coccinellids on pulverized drone honeybee brood. Bull. Fac. Agric. 12: 28-38.

Miller, JR, and AT Miller. 1988. Insect-Plant Interactions. Springer-Verlag. New York.

Nation, JL. 2001. Insect Physiology and Biochemistry. CRC Press. Boca Raton, Fla. $485 \mathrm{p}$.

Niijima, K, M Matsuka, and I Okada. 1986. Artificial diets for an aphidophagous Coccinellid, Harmonia axyridis, and its nutrition (Minreview). In Pp. 37-50. Ecology of Aphidophaga (I Hodek, Ed.). Academia Publ. House, Czechoslovak Acad. Sci., Prague.

Okada, I, H Hoshiba, and T Maehava. 1972. An artificial rearing of a Coccinellid Beetle, Harmonia axyridis Pallas, on pulverized drone honeybee brood. Bull. Fac. Agric. Tamagawa Univ. 12: 39-47.
Omkar, and RB Bind. 2004. Prey quality dependent growth, development and reproduction of a biocontrol agent, Cheilomenes sexmaculata (Fabricius) (Coleoptera: Coccinellidae). Biocont.Sci.Tech. 14(7): 665-673.

Omkar, G Mishra, S Srivastava, AK Gupta. and SK Singh. 2005. Reproductive performance of four aphidophagous ladybirds on cowpea aphid, Aphis craccivora Koch. J. Appl. Entomol. 129(4): 217-220.

Omkar, K Singh, A Pervez. 2006a. Influence of mating duration on fecundity and fertility in two aphidophagous ladybirds. J. Appl. Entomol. 130(2): 103-107.

Omkar, SK Singh, and K Singh. 2006b. Effect on age reproductive attributes of an aphidophagous ladybirds, Cheilomenes sexmaculata. Insect Sci. 13(4): 301-308.

Ross, HH, CA Ross, and RPJ Ross. 1982. A Texkbook of Entomlogy. $4^{\text {th }}$ Ed. John Waley and Sons. New york.

Setiawati, W. 2004. Pemberdayaan dan Pelestarian Parasitoid dan Predator dalam Kerangka Pengelolaan Hama Terpadu Sayuran. Laporan Akhir Proposal. Balitsa. Bandung.

Setiawati, W, SU Tinny, dan KU Bagus. 2004. Pemanfaatan Musuh Alami dalam Pengendalian Hayati Hama pada Tanaman Sayuran. Balai Penelitian Tanaman Sayuran. Pusat Penelitian dan Pengembangan Hortikultura. Badan Penelitian dan Pengembangan Pertanian. Bandung. Tersedia online pada https:/ditjenpkh.pertanian.go.id/perpustaka an/biblembang/index.php?p=show_detail\&i d=800. Diakses 3 Juli 2020.

Szumkowski, W. 1952. Observations on Coccinellidae. II. Experimental Rearing of Coleomegilla on A Non-insect Diet. Trans. IX Intern. Cong. Ent. 1: 781-785.

Thompson, SN. 1999. Nutrition and Culture of Entomophagous Insects. Available online at http://arjournals.annualreviews.org/doi/pdf/ 10.1146/annurev.ento.44.1.561. Diakses 3 Juli 2020.

Untung, K. 2006. Pengantar Pengelolaan Hama Terpadu. Edisi kedua. Gajah Mada University Press. Yogyakarta.

Wagiman, FX. 1997. Ritme aktivitas harian Menochilus sexmaculatus memangsa Aphis craccivora. Prosiding Kongres Perhimpunan Entomologi Indonesia V dan Symposium 
Entomologi "Pengelolaan Serangga Secara Berkelanjutan”. Bandung. Hlm. 278-280.

Wheeler, GS, and J Zahniser. 2001. Artificial diet and rearing methods for the Melaleuca quinquenervia (Myrtale; Myrtaceae) biological control agent Oxyops vitiosa (Coleoptera; Curculionidae). Florida Entomologist. 84 (3): 439-441. 